\title{
Senescence or apoptosis? The choice bovine fibroblasts make in the presence of increasing concentrations of extracellular $\mathrm{H}_{2} \mathrm{O}_{2}$
}

\author{
Andrea Hunt, Dean Betts, W. Allan King, Pavneesh Madan \\ This manuscript was prepared under the supervision of Professor Pavneesh Madan, \\ Department of Biomedical Sciences, Ontario Veterinary College.
}

\begin{abstract}
Reactive oxygen species (ROS) are potent inducers of oxidative damage and have been linked to the regulation of specific cellular functions, including apoptosis. In response to specific signals, mitochondrial $\mathrm{H}_{2} \mathrm{O}_{2}$ can trigger mitochondrial swelling and apoptosis; however, as a protective measure, cells can also enter a state of senescence. The purpose of this study was to determine the effects of extracellular $\mathrm{H}_{2} \mathrm{O}_{2}$ on cellular senescence induction via the mitochondrial ROS-signaling pathway. Bovine fibroblasts were synchronized at the G1/S phase using a thymidinenocodazole mitotic block and treated for two hours with $\mathrm{H}_{2} \mathrm{O}_{2}$ concentrations: $25 \mu \mathrm{M}, 50 \mu \mathrm{M}, 100 \mu \mathrm{M}, 150 \mu \mathrm{M}$ and $200 \mu$ M. Post $\mathrm{H}_{2} \mathrm{O}_{2}$ treatment, the number of floating dead cells was quantified using a hemocytometer. Cells sticking to the bottom of the culture dish were then washed with fresh media and cultured for 24 hours at $39^{\circ} \mathrm{C}$ at $5 \% \mathrm{CO}_{2}$ under humidified conditions and assayed for senescent cell quantification using SA- $\beta$-galactosidase staining assay. Preliminary data indicates that the number of dead cells increased with increasing $\mathrm{H}_{2} \mathrm{O}_{2}$ dosage, with the maximum number of dead cells at $200 \mu \mathrm{m}$ in both cell lines. Along with the increase in number of dead cells, the number of senescent cells decreased up to $50 \mu \mathrm{M}$, and no senescent cells were detected at $\geq 50 \mu \mathrm{m}$ concentrations. This indicates that cells are sensitive to rising levels of $\mathrm{H}_{2} \mathrm{O}_{2}$ and make a choice to enter the senescent or apoptotic pathway based on the oxidative insult they face. Future studies would focus on the molecular mechanism of the mitochondrial-ROS signaling pathway.
\end{abstract}

$\mathrm{O}^{\mathrm{x}}$ xidative stress evolves from the production of reactive oxygen species (ROS), which are naturally occurring substances (oxygen ions, free radicals, peroxides) derived both exogenously through environmental factors and endogenously via mitochondrial production. ${ }^{1}$ Within the mitochondria, a complex series of events leads to the generation of ATP via the electron transport chain, along with the production of ROS as a byproduct. ${ }^{1}$ The presence of ROS leads to oxidative stress -- a common determinant in cellular aging. Currently, the free-radical hypothesis is one of the most accepted theories of aging, as research indicates that aerobic organisms are constantly producing ROS, causing oxidative damage to accumulate over time. ${ }^{1}$ This accumulation can result in such damaging effects as cell death, chromosomal abnormalities and cancer-inducing mutations. While apoptosis has long been recognized as a cellular mechanism used to prevent cellular transformation and cancer, cellular senescence has also been examined for its potential protective effects; however, this protection is believed to come at the cost of cellular aging. ${ }^{2}$

Cellular senescence is a state of permanent cell growth arrest resulting from the inability to divide after a fixed number of cell divisions, as defined by the Hayflick limit. This limit applies a numerical value to somatic cell lines that corresponds to the number of replications cells can undergo before they enter a state of cellular senescence. ${ }^{3}$ Almost all cellular systems exhibit a senescent state (excluding immortalized cells) after a given number of replications, although the onset and progression varies between organisms and tissues. ${ }^{4}$ Cellular senescence is believed to be involved in aging by directly contributing to the functional decline of aging tissues or by indirectly affecting the surrounding nonsenescent cells. ${ }^{1}$

Telomeres, located at the ends of mammalian chromosomes, appear to play a critical role in activating the senescent state. During somatic cell replication, the repetitive telomeric DNA sequence $\left(\right.$ TTAGGG) ${ }^{\mathrm{n}}$ shortens due to the lack of DNA repair mechanisms. ${ }^{5}$ Research has indicated that once telomere length shortens beyond a specific threshold, a p53 dependent pathway is activated that permanently halts cell division. ${ }^{6}$ Recently, it has been shown that telomere 'uncapping' itself can signal the senescent state $^{7}$, which could explain how cells can prematurely enter a state of cell growth arrest despite having long telomeres in vivo or after exposure to oxidative stress. ${ }^{8}$ Research that examined the effects of oxidative stress on telomere length has shown evidence that oxygen free radicals can cause single-stranded breaks in telomeric DNA that accumulate and shorten the replicative lifespan of fibroblasts. ${ }^{9}$ This evidence is strengthened by a study demonstrating that increased antioxidant activity (associated with decreasing the 

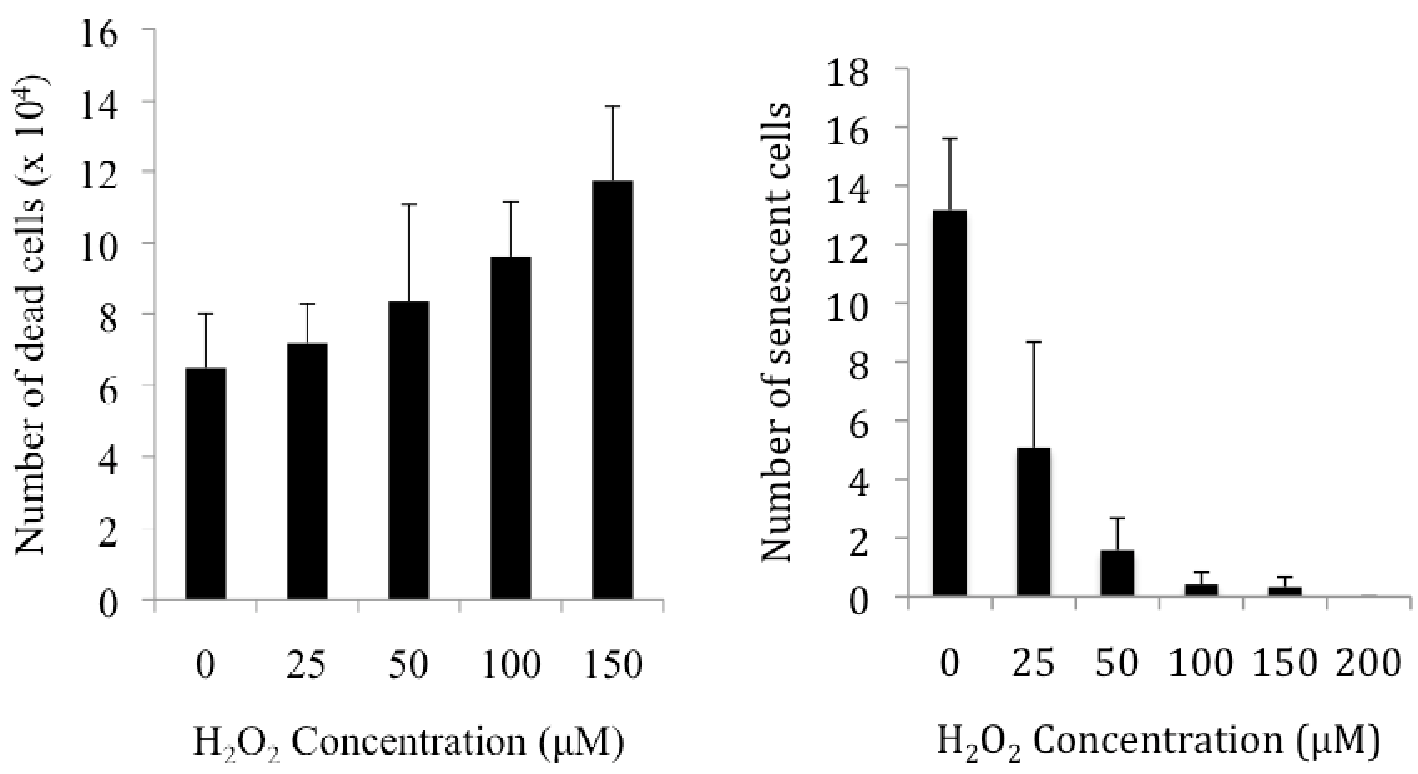

Figure 1. A (left) shows the number of dead bovine fibroblasts ( $\mathrm{M205}$ cell line) resulting from increasing $\mathrm{H}_{2} \mathrm{O}_{2}$ exposure. $\mathrm{B}$ (right) shows the number of bovine fibroblasts ( $\mathrm{M205}$ cell line) in a state of senescence following increasing $\mathrm{H}_{2} \mathrm{O}_{2}$ exposure.

rate of telomere shortening) led to a prolonged lifespan in human fibroblasts. ${ }^{10}$

Based on this evidence, it has been suggested that increased oxidative stress and ROS production can induce and/or accelerate the onset of cellular senescence, as cellular senescence is linked to the redox state of the environment. ${ }^{1}$ In particular, redox enzymes can generate mitochondrial $\mathrm{H}_{2} \mathrm{O}_{2}$ (a type of ROS) in response to specific signals, resulting in mitochondrial swelling and apoptosis. Depending on the amount of mitochondrial ROS produced and its subsequent release from the mitochondria, it has been suggested that cells will either enter a senescent or apoptotic pathway. Therefore the purpose of this study is to determine the effects of extracellular $\mathrm{H}_{2} \mathrm{O}_{2}$ on cellular senescence induction via the mitochondrial ROS-signaling pathway. It is hypothesized that at low concentrations of $\mathrm{H}_{2} \mathrm{O}_{2}$, more cells will choose to enter a state of senescence, whereas at high concentrations of $\mathrm{H}_{2} \mathrm{O}_{2}$, more cells will enter a state of apoptosis.

\section{Materials AND Methods}

\section{Materials}

Hydrogen peroxide, thymidine, nocodazole and DMEM were obtained from Sigma-Aldrich (Oakville, ON). Senescence $\beta$ galactosidase Staining Kit was obtained from Cell Signaling Technology, Inc. (Pickering, ON).

\section{Cell Culture}

Cryogenically frozen bovine fibroblast cells from two different cell lines (1007 and M205) in liquid nitrogen at $-150^{\circ} \mathrm{C}$ were thawed in a $37^{\circ} \mathrm{C}$ waterbath, washed and centrifuged to remove remaining frozen media. Cells were grown on six $35 \mathrm{~mm}$ well culture plates in $2 \mathrm{ml}$ of Dulbecco's modified Eagle medium (DMEM) with 10\% FBS, 1\% PenStrep and 2\% L-glutamine.

\section{Cell Synchronization}

When cells reached $40 \%$ confluency, old media was removed and $2 \mathrm{ml}$ of DMEM (10\% FBS, 1\% Pen-Strep, 2\% Lglutamine) containing $2 \mathrm{mM}$ thymidine was added for $24 \mathrm{~h}$ (S-phase block). After thymidine block, thymidine was removed by washing with $2 \mathrm{ml}$ PBS and fresh DMEM $(10 \%$ FBS, 1\% Pen-Strep, 2\% L-glutamine) was added for $3 \mathrm{~h}$ to release cells. After $3 \mathrm{~h}, 100 \mathrm{ng} / \mathrm{ml}$ nocodazole was added to the media for $12 \mathrm{~h}$ (mitotic block). Nocodazole was removed by washing with $2 \mathrm{ml} \mathrm{PBS}$ and $2 \mathrm{ml}$ of fresh DMEM (10\% FBS, $1 \%$ Pen-Strep, 2\% L-glutamine) was added. Cells then progressed synchronously through G1- and S-phase.

\section{$\mathrm{H}_{2} \mathrm{O}_{2}$ Treatment}

When cells reached $70 \%$ confluency, concentrations of 0,50 , 100,150 and $200 \mu \mathrm{l}$ of $\mathrm{H}_{2} \mathrm{O}_{2}$ in $2 \mathrm{ml}$ DMEM (10\% FBS, $1 \%$ Pen-Strep, 2\% L-glutamine) were added individually to each of the six wells for $2 \mathrm{~h}$. After $2 \mathrm{~h}$, the media containing $\mathrm{H}_{2} \mathrm{O}_{2}$ was removed and stored separately in $15 \mathrm{ml}$ tubes. Each well was replenished with fresh media and returned to the incubator at $39^{\circ} \mathrm{C}$ at $5 \% \mathrm{CO}_{2}$ under humidified conditions for 24 hours.

\section{Dead cell quantification}

Using a hemocytometer and $11 \mu \mathrm{l}$ of media containing $\mathrm{H}_{2} \mathrm{O}_{2}$, the number of dead cells were counted for each $\mathrm{H}_{2} \mathrm{O}_{2}$ concentration (already stored separately in $15 \mathrm{ml}$ tubes) in 

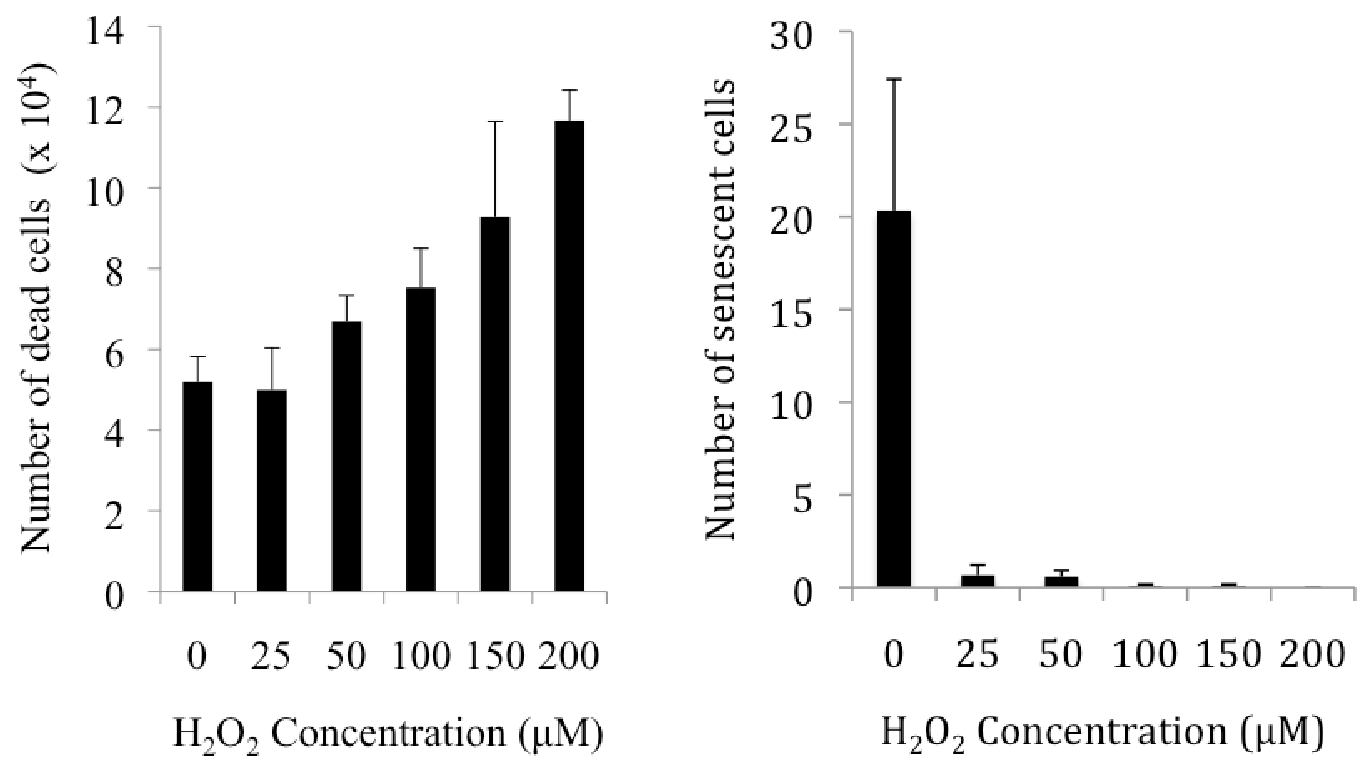

Figure 2: A (left) demonstrates the number of dead bovine fibroblasts (1007 cell line) resulting from increasing $\mathrm{H}_{2} \mathrm{O}_{2}$ exposure. $\mathrm{B}$ (right) demonstrates the number of bovine fibroblasts (1007 cell line) in a state of senescence following increasing $\mathrm{H}_{2} \mathrm{O}_{2}$ exposure.

triplicates. An average was calculated in order to determine the number of dead cells resulting from a specific concentration of $\mathrm{H}_{2} \mathrm{O}_{2}$. This process was repeated for each of the concentrations of $\mathrm{H}_{2} \mathrm{O}_{2}$ used.

\section{SA- $\beta$-galactosidase staining}

$24 \mathrm{~h}$ post $-\mathrm{H}_{2} \mathrm{O}_{2}$ treatment, cells were treated with senescence associated (SA)- $\beta$-galactosidase staining. A 10x staining solution and 10x fixative solution were both diluted with distilled water to make $1 \mathrm{x}$ solutions. The media was removed from the cells and the wells were washed once with $2 \mathrm{ml}$ PBS. The cells were fixed with $1 \mathrm{ml}$ of $1 x$ Fixative Solution for $12.5 \mathrm{~min}$ at room temperature $\left(21^{\circ} \mathrm{C}\right)$. The wells were washed twice with $2 \mathrm{ml} \mathrm{PBS}$ and $1 \mathrm{ml}$ of $\beta$-galactosidase stain (930 $\mu \mathrm{l}$ staining solution, $10 \mu \mathrm{l} 500 \mathrm{mM}$ potassium ferrocyanide, $10 \mu \mathrm{l} 500 \mathrm{mM}$ potassium fericyanide, $50 \mu \mathrm{l} 20$ $\mathrm{mg} / \mathrm{ml} \mathrm{X}$-gal in DMF). Cells were incubated overnight at $39^{\circ} \mathrm{C}$ at $5 \% \mathrm{CO}_{2}$ under humidified conditions.

\section{Imaging}

Images were obtained using phase contrast light microscopy. Four pictures were taken of each well. The number of $\beta$ galactosidase stained cells versus unstained cells were counted and used to calculate a final average ratio of the number of stained to unstained cells in each well.

\section{RESULTS AND DISCUSSION}

This study demonstrates that as the levels of $\mathrm{H}_{2} \mathrm{O}_{2}$ increase, bovine fibroblasts undergo less senescence yet exhibit higher apoptotic levels. The number of dead cells increased with increasing $\mathrm{H}_{2} \mathrm{O}_{2}$ dosage, with the maximum number of dead cells at $200 \mu \mathrm{m}$ in both cell lines (Figure $1 \mathbf{A}$ and $\mathbf{2 A}$ ). At the same time, as concentrations of $\mathrm{H}_{2} \mathrm{O}_{2}$ increase, the number of senescent cells in both cell lines decreased up to $150 \mu \mathrm{M}$ and no senescent cells were detected at concentrations of $200 \mu \mathrm{M}$ (Figure 1B and 2B). This suggests that at low levels of $\mathrm{H}_{2} \mathrm{O}_{2}$, cells can enter a senescent state as a protective mechanism, however as the level of $\mathrm{H}_{2} \mathrm{O}_{2}$ increases, it overwhelms the senescent state induced-protection causing an increase in cell damage. This results in the cell entering an apoptotic state instead. These results were found for both cell lines, suggesting that a variety of bovine fibroblast cells all respond in the same manner following exposure to $\mathrm{H}_{2} \mathrm{O}_{2}$.

One limitation of this study is the levels of senescence were found to be higher than expected in untreated cells. This could be due to the number of cell passages completed, as the cells were treated with $\mathrm{H}_{2} \mathrm{O}_{2}$ at passage twelve. Research has shown that the level of senescence of cultured bovine fibroblasts does not vary greatly until they have been passaged over twenty times, indicating that high passage rates most likely are not the cause of the high senescence levels. As well, unpublished data from this lab of younger cells (passage 4/5) that were unsynchronized demonstrated similar results in the control group. Another potential cause of the high levels of senescence is oxygen tension levels, as high oxygen tension has been associated with an increase in senescence. ${ }^{1}$ Attempts were made to control for high oxygen tension as cells were stored in low oxygen-incubators in order to limit the potential interaction between cells and high oxygen tension.

$\beta$-galactosidase staining also demonstrated some of the morphological changes that are characteristic of senescent cells such as gross enlargement and binucleation (Figure 3). 

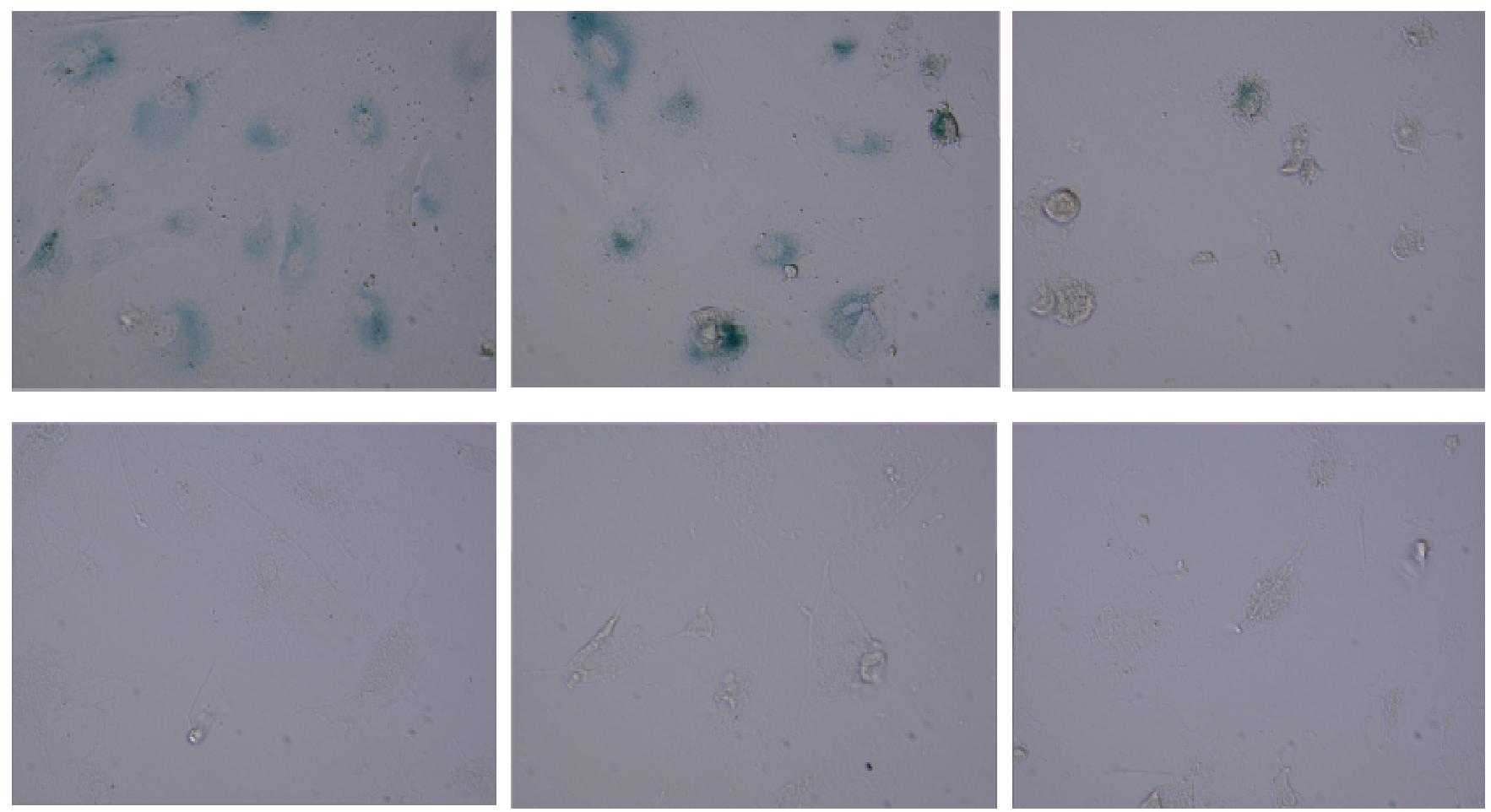

Figure 3: Demonstrates bovine fibroblasts (M205 cell line) treated with $\mathrm{SA}-\beta$ galactosidase post- $\mathrm{H}_{2} \mathrm{O}_{2}$ treatment. Top row from left to right: $0 \mu \mathrm{M}, 25 \mu \mathrm{M}, 50 \mu \mathrm{M}$ of $\mathrm{H}_{2} \mathrm{O}_{2}$. Bottom row, left to right: $100 \mu \mathrm{M}, 150 \mu \mathrm{M}, 200 \mu \mathrm{M}$ of $\mathrm{H}_{2} \mathrm{O}_{2}$.

As the concentration of $\mathrm{H}_{2} \mathrm{O}_{2}$ increased, the cells also began to appear more fragmented and of variable densities. This variation is indicative of a damaged cell undergoing apoptosis (as characterized by unpublished data obtained from this lab) and further strengthens the results from Figure 1 and 2.

In conclusion, these results demonstrate that an inverse proportional relationship exists between $\mathrm{H}_{2} \mathrm{O}_{2}$ exposure and cells in senescence; however, increasing levels of $\mathrm{H}_{2} \mathrm{O}_{2}$ elicit a directly proportional change in apoptotic levels. This indicates that cells are sensitive to rising levels of $\mathrm{H}_{2} \mathrm{O}_{2}$ and make a choice to enter the senescent or apoptotic pathway based on the oxidative insult they face. While this research has direct implications for all age-related diseases, such as Parkinson's and Alzheimers, and may have potential to prevent, reverse or slow down cellular aging, mechanisms by which cellular senescence occurs need to be further elucidated.

\section{FUTURE EXPERIMENTATION}

Future studies will look at MitoSox staining to directly examine changes in superoxide levels in the mitochondria in order to determine the specific level of mitochondrial ROS production. In order to further characterize the mitochondrial ROS signaling pathways, changes in specific gene expression of proteins involved in the pathway should be examined. Flow cytometry can also be used to further characterize the dead cells in order to unequivocally demonstrate that they are in a state of apoptosis.

\section{ACKNOWLEDGMENTS}

This study was funded by the Canadian Institute for Health Research.

\section{REFERENCES}

1. Giorgio, M., Trinei, M., Migliaccio, E., Pelicci, P.G. (2007). Hydrogen peroxide: a metabolic by-product or a common mediator of ageing signals? Nature Reviews Molecular Cell Biology. 8: 722-728.

2. Campisi, J. (2001). Cellular senescence as a tumoursuppressor mechanism. Trends Cell Biol. 11: S27-31.

3. Hayflick, L. (1965). The limited in vitro lifetime of human diploid cell strains. Exp Cell Res. 37: 614-636.

4. Hayflick, L., Moorhead, P.S. (1961). The serial cultivation of human diploid cell strains. Exp Cell Res. 25: 585-621.

5. Harley, C.B., Futcher, A.B., Greider, C.W. (1990). Telomeres shorten during ageing of human fibroblasts. Nature. 345 (6274): 458-460.

6. Vaziri, H., Benchimol, S. (1998). Reconstitution of telomerase activity in normal human cells leads to elongation of telomeres and extended replicative life span. Curr Biol. 8(5): 279-82. 
7. Stewart. S.A (2003). Erosion of the telomeric single-strand overhang at replicative senescence. Nat Genet, 33(4): 492496.

8. Betts, D.H., King, W.A. (1999). Telomerase activity and telomere detection during early bovine development. Dev Genet. 25(4): 397-403.
9. Petersen, S., Saretzki, G., von Zglinicki, T. (1998). Preferential accumulation of single-stranded regions in telomeres of human fibroblasts. Exp Cell Res. 239(1): 153160 .

10. Serra, V. et al. (2003). Extracellular superoxide dismutase is a major antioxidant in human fibroblasts and slows telomere shortening. J Biol Chem. 278(9): 6824-6830. 